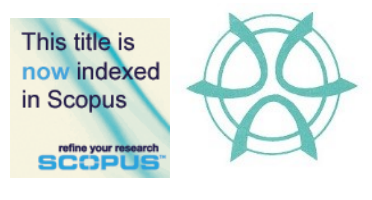

PLANNING MALAYSIA:

Journal of the Malaysian Institute of Planners

VOLUME 19 ISSUE 3 (2021), Page 260 - 269

\title{
A PROPOSAL FOR AFFORDABLE WAQF HOUSING PROJECTS IN MALAYSIA: PUBLIC PERCEPTION OF HOUSE CHARACTERISTICS
}

\author{
Nor Azizan Che Embi ${ }^{1}$, Salina Kassim ${ }^{2}$, Roslily Ramlee ${ }^{3}$, Wan Rohaida \\ Wan Husain ${ }^{4}$ \\ ${ }^{1,3,4}$ Kulliyyah of Economics and Management Sciences \\ ${ }^{2}$ IIUM Institute of Islamic Banking and Finance \\ INTERNATIONAL ISLAMIC UNIVERSITY MALAYSIA
}

\begin{abstract}
Housing affordability is important to ensure houses are affordable to everyone across all income categories, whether they are in the low-income, middle-income (M40), or high-income group. Building housing projects on waqf land will help increase the supply of affordable houses, especially targeted at the M40 group, while also addressing the shortage of affordable housing for the M40 cohort. This study analyses public perceptions of house characteristics and relate these factors to affordable housing prices. The independent variables are location, infrastructure, facilities, size, design and quality. By applying a quantitative research design, the study aims to understand the relationship between various demanded housing characteristics vis-à-vis the price of the house. A sample of 261 usable responses was analysed using the Structural Equation Modelling (SEM). The results show that house size is not statistically significant in influencing the housing price, while location, infrastructure and design of the house are positively significant factors. These findings are expected to provide important inputs to the relevant authorities on factors that are critical in influencing the prices of housing projects built on waqf land in Malaysia.
\end{abstract}

Keywords: Housing Affordability, Housing Price, Middle Income Group (M40), Waqf

\footnotetext{
${ }^{1}$ Assistant Professor Dr. Nor Azizan Che Embi, International Islamic University Malaysia. Email: izanebbm@iium.edu.my
} 
PLANNING MALAYSIA

Journal of the Malaysia Institute of Planners (2021)

\section{INTRODUCTION}

In Malaysia, efforts have been made by policymakers to understand and manage affordable housing issues. This effort has led to several initiatives focusing on providing affordable houses or financial resources to low-income households who by nature, are incapacitated to house themselves. However, the gap left unfilled by these initiatives is middle-income households (M40) who neither qualify for social housing nor are capable of affording houses provided by private sector suppliers (Baqutaya et al., 2016; Khazanah Research Institute, 2015). The issue of a shortage of affordable housing requires immediate attention since most of the conventional methods used in the property market lack the capacity to supply affordable housing. While several houses are unsold, a sizeable number of middle-income households are still looking for reasonably priced and affordable houses to buy. The use of waqf land on which the affordable houses will be constructed would help reduce the construction costs substantially. This will lead to more reasonable pricing of the houses.

\section{RESEARCH BACKGROUND}

The Malaysian government has acknowledged that housing is a basic human need and one of the important components in the urban economy (Suhaida, Norngainy, Noraini, Adi Irfan, \& Tahir, 2010). While Malaysia has made immense contributions towards providing affordable housing, especially to low-income households, affordable housing providers are faced with serious resistance over their products because they are generally unaffordable for middle-income households. Consequently, the housing contribution to the quality of life in urban areas is deteriorating since housing providers cannot produce houses at prices that middle-income households would be able to afford (Hong, 2013; Ernawati, Kong Seng \& Nor A'ini, 2020). However, it should be noted that house prices in Malaysia are deeply dependent on location, with some states having more affordable housing. For example, Melaka with median multiple of 3.0 times compared to others; the house prices in other states, such as Kuala Lumpur (5.4 times) and Pulau Pinang (5.2 times) are strictly unaffordable (Khazanah Research Institute, 2015). Location has influence towards housing affordability (M. Azren, Hazlina, Jamalunlaili \& Yusfida Ayu, 2018). Data in the Annual Property Market Report 2016 and 2020 by the National Property Information Centre (NAPIC) reveals that a considerable amount of completed and under construction residential units are currently not demanded by Malaysian households.

Table 1 indicates more than 14,000 completed residential units are unsold as of the third quarter of 2016 and in Table 2, the amount increases further in fourth quarter of 2020. From Table 1, 4,646 completed residential units are priced below RM250,000, 4,120 units are priced between RM250,001RM500,000, and 5,427 units are priced above RM500,001. In addition, 14,792 units of house under residential were overhang in 2016 and in 2020 it increases 
Nor Azizan, Salina, Roslily \& Wan Rohaida

A Proposal for Affordable Waqf Housing Projects in Malaysia: Public Perception of House Characteristics

to 29565 units. Surprisingly, an estimated one million Malaysian households in the RM2,500 to RM10,000 monthly income group do not own a house as of $2016^{1}$.

Table 1: Launched and Unsold Residential Properties

\begin{tabular}{|l|c|c|c|}
\hline House Category & $\begin{array}{c}\text { Units } \\
\text { Launched }\end{array}$ & Units Unsold & $\begin{array}{c}\text { Value (RM } \\
\text { Mill) }\end{array}$ \\
\hline Below RM250,000 & 23,849 & 4,646 & 624.7 \\
\hline RM250,001-RM500,000 & 13,730 & 4,120 & $1,512.1$ \\
\hline Above RM500,001 & 25,233 & 5,427 & $6,130.7$ \\
\hline Total & $\mathbf{6 2 , 8 1 2}$ & $\mathbf{1 4 , 1 9 3}$ & $\mathbf{8 , 2 6 7 . 4}$ \\
\hline
\end{tabular}

Table 2: Residential Overhang Properties in 2020

\begin{tabular}{|l|c|}
\hline House Category & Units Unsold \\
\hline Below RM100,000 & 1,209 \\
\hline RM100,001-RM300,000 & 7,549 \\
\hline RM300,001-RM500,000 & 7,116 \\
\hline RM500,001-RM700,000 & 6,607 \\
\hline Total & $\mathbf{2 2 , 4 8 1}$ \\
\hline
\end{tabular}

Based on the data reported in Tables 1 and 2, we can deduce that most low and middle-income households do not own a house because they cannot afford to purchase the house due to the price being beyond their reach. The house prices according to NAPIC (2020) still seriously unaffordable therefore the quantities of unsold housing units remain huge. This is consistent with the study by Liu and Ong (2021). Although there are a significant number of unsold houses, a considerable number of middle-income households are still looking for reasonably priced and affordable houses to buy. Bank Negara Malaysia ${ }^{2}$ reported that Malaysian middle-income households with the household income brackets of RM6,000 to RM7,999 are in need of houses priced less than RM408,300. The price of RM408,300 is considered the affordability threshold. There is suggestion that proposed selling price should be monitor by the Government (Ernawati, et al., 2020)

In short, the houses available in the market currently are unaffordable to middle-income groups, and with their current level of income, they may not be

\footnotetext{
${ }^{1}$ Cindy Yeap (2017), state of the nation: unsold units reflect mismatch in supply and demand for affordable housing, retrieved from http://www.theedgemarkets.com/my/article/state-nation-unsold-units-reflectmismatch-supply-and-demand-affordable-housing

2 Cheah S. Ling, Stefanie Almeida, Muhamad Shukri and Lim Le Sze, (2017) Imbalances in the Property Market. Bank Negara Malaysia. 
PLANNING MALAYSIA

Journal of the Malaysia Institute of Planners (2021)

able to secure a home loan or financing from financial institutions to finance the purchase of a house. This issue requires immediate attention from the government, government bodies or relevant authorities to find solutions or mechanisms to provide more affordable homes for this cohort. This study proposes using waqf as an alternative financing mechanism to provide affordable houses to middle-income (M40) households. Due to the global financial crisis, land mitigation, and global environmental issues, the country faces design innovation and policy evolution (Lim, 2016 and Malaysia Productivity Corporation, 2010). Thus, the Malaysian government has adopted a creative design approach and various incentives to increase the number of affordable houses.

In the Muslim world, many humanitarian projects are operated by waqf institutions. Among their large scale waqf projects is building houses for the needy. In the context of Malaysia, building housing projects on waqf land will help increase the supply of affordable houses, especially targeted at the middleincome (M40) group, thus addressing the issue of shortages of affordable houses for the M40. In Malaysia, the prospects and demand from the public to rent the waqf houses are high due to affordable rental rates. In view of this, the best option by State Islamic Religious Councils (SIRCs) in managing their waqf land is to develop affordable houses so that the waqf land is productively developed as well as getting lump sum rental income. Currently, these initiatives are actively undertaken by SIRCs in Kedah and Pulau Pinang (UDA Holdings Berhad, 2019).

\section{RESEARCH METHODOLOGY}

By applying a quantitative research design, the study aims to understand the relationship between various housing demanded characteristics with the price of the house. The definition of population in this study are middle-income Muslim households in Malaysia. Due to limitations in gaining feedback from Sabah and Sarawak, the study only focuses on middle-income Muslim groups in Peninsular Malaysia. A sample of 261 usable responses was collected using the purposive sampling method. The sample size between 200 to 300 respondents was appropriate and fair according to the scale suggested by Comrey and Lee (1992) and cited by Tabachnick \& Fidell (1996). A set of questionnaires with four parts was designed to collect various responses from the respondents. The first part addresses the demographic profiles of respondents. The second part targets the public knowledge of affordable housing projects built on waqf land in Malaysia. Among the aims in part three of the questionnaire is to understand the relationship between various housing characteristics vis-à-vis the price of the house. The last part of the questionnaire covers the public perception of several aspects of the proposed waqf financing model. This paper only reports part of the findings from part three. The independent variables that reflect housing characteristics are location, infrastructure, facilities/amenities, size, design, and quality, while price 
Nor Azizan, Salina, Roslily \& Wan Rohaida

A Proposal for Affordable Waqf Housing Projects in Malaysia: Public Perception of House Characteristics

is the dependent variable. The data were analysed with the Structural Equation Modelling (SEM) using Analysis of Moment Structure (AMOS) software.

\section{ANALYSIS}

This analysis was performed to determine the relationships between independent variables such as location, infrastructure, facilities/amenities, size, design, and quality with price for the housing project. The response from statements reflecting the demanded housing characteristics was measured using a five-point Likert scale where respondents indicated their disagreement or agreement on each given statement. The results of Composite Reliability (CR) reflect the validity of the samples used in this study. The cutting point of $\mathrm{CR}$ value must be greater than 0.6. Based on Table 3, all variables have $\mathrm{CR}$ values greater than 0.6. The assessment of sample fitness, measured by the Kaiser-Meyer-Olkin (KMO) test, is adequate at 0.853 .

Table 3: Reliability Statistics

\begin{tabular}{llcc}
\hline Number & Variable & Number of item & Composite reliability \\
1 & Location & 4 & 0.797 \\
2 & Infrastructure & 4 & 0.825 \\
3 & Facilities/Amenities & 4 & 0.761 \\
4 & Size & 5 & 0.762 \\
5 & Design & 4 & 0.738 \\
6 & Quality & 4 & 0.726 \\
7 & Price & 4 & 0.768 \\
\hline
\end{tabular}

Table 4: KMO and Bartlett's Test

\begin{tabular}{llr} 
Kaiser- Meyer-Olkin Measure of sampling adequacy & .853 \\
Bartlett's Test of Sphericity & Approx Chi-square & 2540.980 \\
& $\mathrm{df}$ & 351 \\
& Sig & .000 \\
\hline
\end{tabular}

The results of Bartlett test of Sphericity $\left(\mathrm{X}_{2}=2540.980, p\right.$-value $\left.=0.000\right)$ suggest a correlation between variable exist, as described in Table 4 . Confirmatory Factor Analysis (CFA) was performed to assess and develop the measurement model (Figure 1) in order to specify how well the measured variables, come together to represent latent variables (i.e., constructs). All the seven latent variables generated during the Exploratory Factor Analysis are retained after CFA. However, few of the observed (items) were eliminated during the analysis. 
Figure 1: Confirmatory Factor Analysis

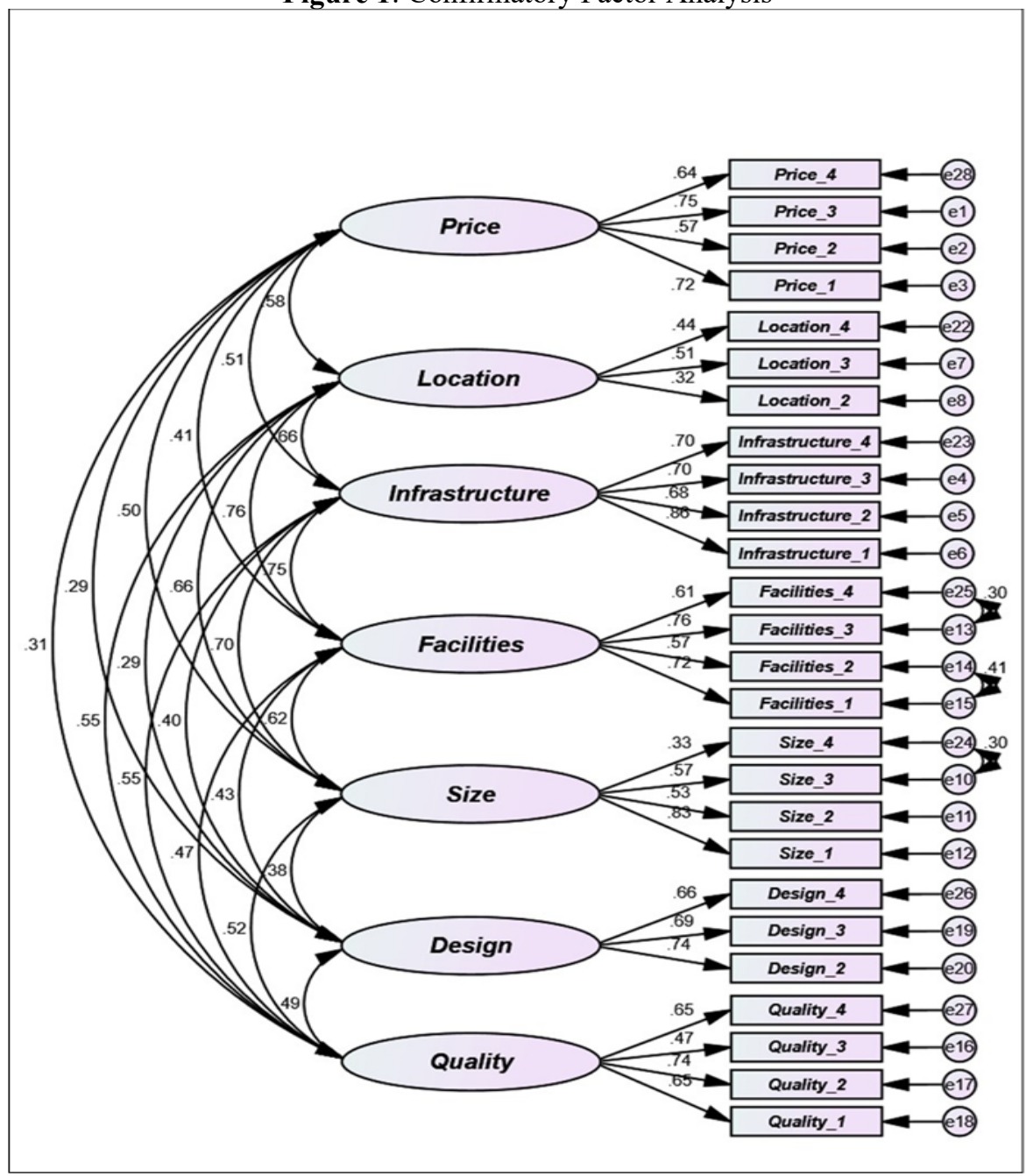

Source: Authors

The model met the model fit criteria. The results of minimum discrepancy per degree of freedom (CMIN/DF), Comparative Fit Index (CFI), Standardised Root Mean Square Residual (SRMR), Root Mean Square Error of Approximation (RMSEA) and the chi-square value (PClose) are reported in Table 5. The interpretation for model fit criteria based on Hu. L-t., and Bentler, P. M. (1999) and Gaskin, J. \& Lim, J. (2016) shows that the model in this analysis met the model fit criteria. 
Nor Azizan, Salina, Roslily \& Wan Rohaida

A Proposal for Affordable Waqf Housing Projects in Malaysia: Public Perception of House Characteristics

Table 5: Regression Weights

\begin{tabular}{cccc}
\hline Measure & Estimate & Threshold & Interpretation \\
\hline CMIN & 495.041 & -- & -- \\
DF & 275 & -- & -- \\
CMIN/DF & 1.800 & Between 1 and 3 & Excellent \\
CFI & 0.900 & $>0.95$ & Acceptable \\
SRMR & 0.058 & $<0.08$ & Excellent \\
RMSEA & 0.055 & $<0.06$ & Excellent \\
PClose & 0.124 & $>0.05$ & Excellent \\
\hline & Source: Hu. L-t., and Bentler, P. M. (1999) and Gaskin, J. \& Lim, J. (2016)
\end{tabular}

SEM analysis was performed to determine the relationships between independent variables (location, infrastructure, facilities/amenities, size, design, and quality) and dependent variable (price for housing project). As presented in Figure 2 and Table 6 below, three variables were found to be positively and significantly contribute to the price of housing. The variables are, location, infrastructure and design. The results are location $(\beta=1.970, \mathrm{p}<0.05)$, infrastructure $(\beta=.484, \mathrm{p}<$ $0.05)$, and design $(\beta=.434, p<0.05)$. With these results, we conclude that a house buyer prefers a house that is close to college, school and workplace and agreed to compensate it with a slightly higher price. Therefore, respondents regarded location as an important house characteristic. The results show that house buyers agreed to pay more if the housing projects have a proper road infrastructure plan, have adequate water supply, have facilities for the disabled, and without electricity supply interruptions.

Interestingly, design is also an important house characteristic to house buyers who agree to pay more for a good design. Among the designs are houses built as disabled-friendly, the positioning of the rooms that considers the position of Qiblat, etc. From the results, house characteristics such as location, infrastructure and design are very important factors to house buyers who will consider paying more to have such characteristics. 


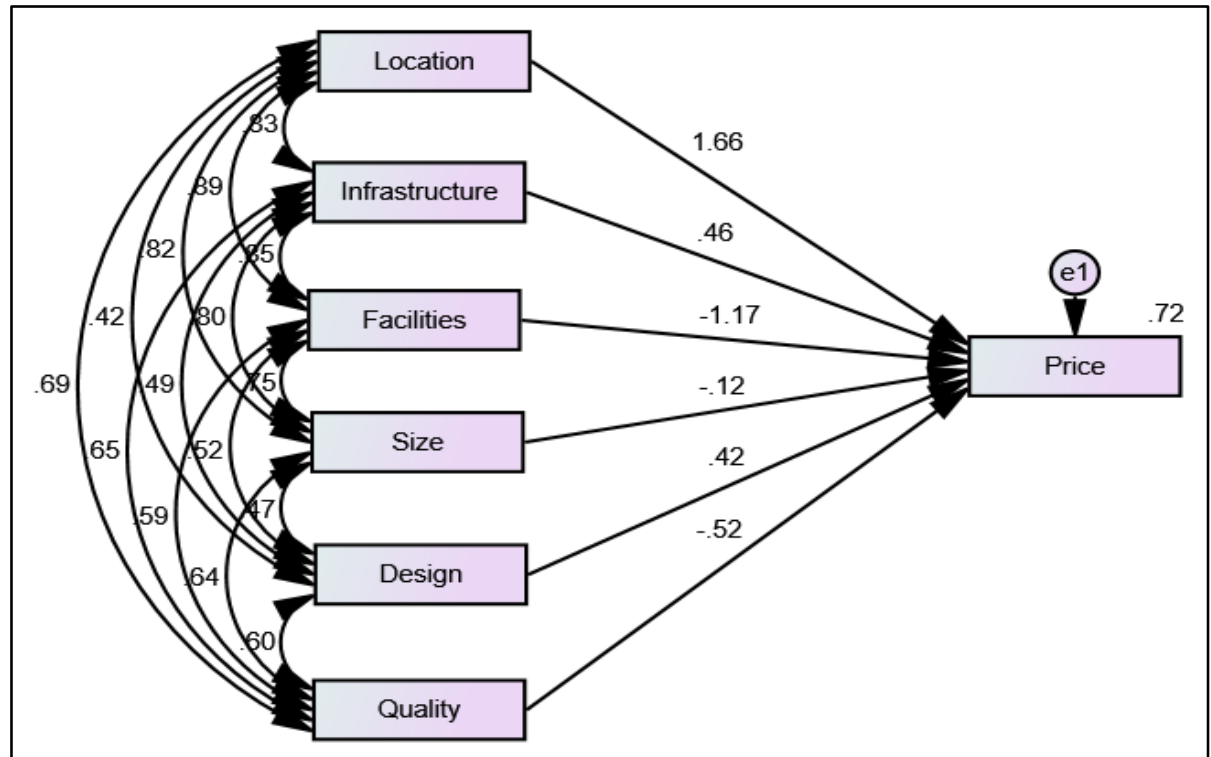

Figure 2: Structural Model

Source: Authors

From the results, we found that facilities and quality are negatively significant, where facilities, $(\beta=-1.323, \mathrm{p}<0.05)$ and quality $(\beta=-.626, \mathrm{p}<0.05)$. The result reflects that house buyers are particular about the house facilities. They are also concerned with the price the developer will charge. The result shows that house buyers prefer housing projects with many facilities at affordable prices. Quality of the house is also an important characteristic for house buyers and is associated with price. The result shows that house buyers want a quality house at an affordable price. However, size $(\beta=-.150, p>0.05)$, is negatively and insignificantly related to the price of houses. This means the house size is not statistically significant in influencing the housing price. Based on these findings, the study supported five hypotheses and rejected one hypothesis where we conclude that location, infrastructure, design, facilities, and quality are significantly related to the price for housing, while size does not influence the housing price. Therefore, the hypothesis concerning size was rejected.

Table 6: Regression Weights

\begin{tabular}{llrrrc}
\hline & & Estimate & S.E. & C.R. & P \\
\hline Price $<---$ & Location & 1.970 & .114 & 17.209 & $* * *$ \\
Price $<---$ & Infrastructure & .484 & .077 & 6.279 & $* * *$ \\
Price $<---$ & Facilities & -1.323 & .102 & -12.915 & $* * *$ \\
Price $<---$ & Size & -.150 & .081 & -1.854 & .064 \\
Price $<---$ & Design & .434 & .048 & 9.053 & $* * *$ \\
Price $<---$ & Quality & -.626 & .065 & -9.561 & $* * *$ \\
\hline
\end{tabular}


Nor Azizan, Salina, Roslily \& Wan Rohaida

A Proposal for Affordable Waqf Housing Projects in Malaysia: Public Perception of House Characteristics

\section{CONCLUSION}

The results show that house size is not statistically significant in influencing the housing price, while location, infrastructure and design of the house are very important factors. These findings are expected to provide important inputs to the relevant authorities on factors that are critical in influencing the prices of affordable housing projects built on waqf land in Malaysia. Therefore, in setting the price for affordable waqf housing in Malaysia and increasing the demand for such a housing project, waqf institutions must emphasise the house characteristics demanded by house buyers.

\section{ACKNOWLEDGEMENTS}

This research was supported by the National Real Property Research Coordinator (NAPREC), National Institute of Valuation (INSPEN), Valuation \& Property Services Department (JPPH Malaysia) and Ministry of Finance, Malaysia through grant allocation under Project ID: SP18-152-0414

\section{REFERENCES}

Annual Property Market Report (2016), National Property Information Centre. https://napic.jpph.gov.my/portal/web/guest/main-page

Annual Property Market Report (2020), National Property Information Centre. https://napic.jpph.gov.my/portal/web/guest/main-page

Baqutaya, S., Ariffin, a. S., \& Raji, F. (2016). Affordable Housing Policy: Issues and Challenges Among Middle-Income Groups. International Journal of Social $\begin{array}{llll}\text { Science Humanity, } & \text { 6(6), 433-436. }\end{array}$ https://doi.org/10.7763/IJSSH.2016.V6.686

Cheah S. L., Stefanie A., Muhamad S. \& Lim L. S., (2017) Imbalances in the Property Market. Bank Negara Malaysia.

Cindy Y. (2017), State of the Nation: Unsold Units Reflect Mismatch in Supply and Demand for Affordable Housing, retrieved from http://www.theedgemarkets.com/my/article/state-nation-unsold-units-reflectmismatch-supply-and-demand-affordable-housing

Comrey, A. L., \& Lee, H. B. (1992). A First Course in Factor Analysis (2 ${ }^{\text {nd. ed.). }}$ Lawrence Erlbaum Associates, Inc.

Ernawati M. K., Kong S. L. \& Nor'Aini Y. (2020). The Low-Middle Income Housing Challenges in Malaysia, Journal of the Malaysian Institute of Planners, Vol. 18 (1) $102-117$

Gaskin, J. \& Lim, J. (2016), "Model Fit Measures”, AMOS Plugin. Gaskination's StatWiki.

Hong, T. T. (2013). Affordable Housing for First-Time Homebuyers: Issues and Implications from the Malaysian Experience. Pacific Rim Property Research Journal, 19(2), 199-210. https://doi.org/10.1080/14445921.2013.11104381

Hu. L-t., and Bentler, P.M. (1999). Cut-off Criteria for Fit Indexes in Covariance Structure Analysis: Conventional Criteria Versus New Alternatives. Structural Equation Modelling, 6(1), 1-55. 
Khazanah Research Institute. (2015). Making Housing Affordable. Retrieved from www.KRInstitute.org

Lim, S. (2016). Affordable Housing and the Emergence of a New Norm. The Edge Property. https://www.edgeprop.my/content/959872/affordable-housing-andemergence-new-norm

Liu J. \& Ong H. Y. (2021). Can Malaysia's National Affordable Housing Policy Guarantee Housing Affordability of Low-Income Households? Journal of Sustainability, Vol. 13 https://doi.org/10.3390/su13168841

Malaysia Productivity Corporation. (2010). Sustainable Development Initiatives in Malaysia. http://www.mpc.gov.my/wp-content/uploads/2016/04/SustainableDevelopment-Initiatives-In-Malaysia.pdf

M. Azren H., Hazlina H., Jamalunlaili A. \& Yusfida Ayu A. (2018). Housing and Transportation Expenditure: An Assessment of Location Housing Affordability, Journal of the Malaysian Institute of Planners, Vol. 16 (2) 99-108.

Suhaida, M. S., Norngainy M.T., Noraini H., Adi Irfan C.A.\& Tahir, M. M. (2010). A Conceptual Overview of Housing Affordability in Selangor, Malaysia. World Academy of Science, Engineering and Technology, 72, 45-47. https://doi.org/10.1016/j.proeng.2011.11.176

Tabachnick, B. G., \& Fidell, L. S. (1996). Using multivariate statistics (3rd ed.). New York: HarperCollins.

UDA Holdings Berhad (2019). UDA First Global Waqf Conference Recognition Awards. https://prebiu.com/2019/11/21/uda-raih-anugerah-1st-global-waqf-conferencerecognition-awards/

Received: $12^{\text {th }}$ July 2021 . Accepted: $17^{\text {th }}$ Sept 2021 